\title{
Dialister micraerophilus sp. nov. and Dialister propionicifaciens sp. nov., isolated from human clinical samples
}

Correspondence

Hélène Marchandin

h-marchandin@chu-montpellier.fr

\author{
Estelle Jumas-Bilak, ${ }^{1}$ Hélène Jean-Pierre, ${ }^{2}$ Jean-Philippe Carlier, ${ }^{3}$ \\ Corinne Teyssier, ${ }^{1}$ Kathryn Bernard, ${ }^{4}$ Bernard Gay, ${ }^{2}$ Josiane Campos, ${ }^{2}$ \\ Florent Morio ${ }^{2}$ and Hélène Marchandin ${ }^{2}$
}

\author{
${ }^{1}$ Laboratoire de Bactériologie-Virologie, Faculté de Pharmacie, 15 Avenue Charles Flahault, \\ BP 14491, 34060 Montpellier Cedex 5, France
²Laboratoire de Bactériologie, Hôpital Arnaud de Villeneuve, 371 Avenue du Doyen Gaston Giraud, 34295 Montpellier Cedex 5, France \\ ${ }^{3}$ Centre National de Référence des Bactéries Anaérobies et du Botulisme, Institut Pasteur,
25 rue du Dr Roux, 75724 Paris Cedex 15, France
}
${ }^{4}$ National Microbiology Laboratory - Public Health Agency of Canada, 1015 Arlington St, Suite H5040, Winnipeg, MB, Canada R3E 3R2

\begin{abstract}
Seventeen anaerobic, Gram-negative, tiny coccobacilli were collected in France from various human clinical samples. Biochemical analyses as well as molecular studies, including 16S rRNA and dnaK gene sequencing, affiliated all the isolates to the genus Dialister. However, 16S rRNA and dnaK gene sequence similarities were below $95 \cdot 2$ and $79 \cdot 7 \%$, respectively, when comparisons were performed with the currently described species Dialister pneumosintes and Dialister invisus. Two clusters consisting of 13 and four isolates could be differentiated. $16 \mathrm{~S}$ rRNA- and $d n a K$-based phylogeny confirmed that these two clusters represent two novel and distinct lineages within the genus Dialister. Finally, phenotypic, genotypic and phylogenetic data supported the proposal of the two novel species Dialister micraerophilus sp. nov. (type strain ADV $04.01^{\top}=$ AIP $25.04^{\top}=$ CIP $108278^{\top}=$ CCUG $48837^{\top}$ ) and Dialister propionicifaciens sp. nov. (type strain ADV $1053.03^{\top}=$ AIP $26.04^{\top}=$ CIP $108336^{\top}=$ CCUG $49291^{\top}$ ). The G $+C$ content of the DNA of the D. micraerophilus type strain is $36.3 \mathrm{~mol} \%$. On the basis of $16 \mathrm{~S}$ rRNA gene sequence analysis, 11 isolates originating from Canada could also be affiliated to D. micraerophilus sp. nov., and were included in the species description.
\end{abstract}

The genus Dialister (Bergey et al., 1923) was revived by Moore \& Moore (1994) to accommodate a rod-shaped Gram-negative bacillus previously classified as Bacteroides pneumosintes (Holdeman \& Moore, 1970), and its description was emended in 2003 (Downes et al., 2003). At present, the genus comprises the two species Dialister pneumosintes and Dialister invisus (Downes et al., 2003).

Published online ahead of print on 15 July 2005 as DOI 10.1099/ ijs.0.63715-0.

The GenBank/EMBL/DDBJ accession numbers for the 16S rRNA gene sequences of $D$. micraerophilus $A D V 04.01^{\top}$ and $D$. propionicifaciens ADV $1053.03^{\top}$ are AF473837 and AY850119, respectively, and the accession numbers of the $d n a K$ gene sequences of these strains are respectively AY851488 and AY851500.

An evolutionary distance tree, based on partial 16S rRNA gene sequences, and a table of the cellular fatty acid compositions of $D$. micraerophilus and $D$. pneumosintes are available as supplementary material in IJSEM Online.
The 28 strains studied were recovered on Columbia sheepblood agar (bioMérieux) after incubation at $37^{\circ} \mathrm{C}$ for $2-5$ days in an anaerobic jar with the Anaerogen System (Oxoid Unipath), and are listed in Table 1. It is noteworthy that the pattern of sites of isolation differed from those historically reported for Dialister spp. (Goldstein et al., 1984; Doan et al., 2000; Paster et al., 2001; Rolph et al., 2001; Rousée et al., 2002; Domann et al., 2003; Downes et al., 2003) in that several isolates of this study were grown from infradiaphragmatic samples (Table 1). All of these isolates were subjected to further polyphasic investigation, but the approaches used on the French and Canadian isolates did not include strictly the same analyses and are presented successively below.

The 16S rRNA gene and the $70 \mathrm{kDa}$ heat-shock-protein gene $(d n a K)$ were selectively amplified by PCR from DNA of the 17 French isolates and sequenced as described previously (Carlier et al., 2002; Marchandin et al., 2003b). 
Table 1. Characteristics of the 28 clinical isolates studied in this work

Strains labelled 'ADV' were from University Hospital Arnaud de Villeneuve, Montpellier, France. They were recovered in mixed cultures from various samples collected from 17 different patients between March 2001 and January 2004. Strains labelled 'NML' were referred to the National Microbiology Laboratory of the Public Health Agency of Canada, over an 8-year period, from patients located in British Columbia, Alberta, Manitoba, Ontario and Quebec.

\begin{tabular}{|c|c|c|}
\hline Strain & Age (years) and sex of patient ${ }^{*}$ & Clinical specimen \\
\hline \multicolumn{3}{|c|}{ D. micraerophilus sp. nov. } \\
\hline $\mathrm{ADV} 04.01^{\mathrm{T}}$ & $38, \mathrm{~F}$ & Amniotic fluid \\
\hline ADV 253.01 & $39, \mathrm{M}$ & Pilonidal cyst \\
\hline ADV 1368.02 & $65, \mathrm{~F}$ & Pilonidal cyst \\
\hline ADV 2470.02 & $35, \mathrm{~F}$ & Abscess (anus) \\
\hline ADV 3269.02 & $34, \mathrm{M}$ & Abscess (buttock) \\
\hline ADV 4318.03 & $17, \mathrm{~F}$ & Pilonidal cyst \\
\hline ADV 1413.03 & $21, \mathrm{~F}$ & Amniotic fluid \\
\hline ADV 5290.03 & $41, \mathrm{M}$ & Bone \\
\hline ADV 7057.03 & $21, \mathrm{~F}$ & Bartholin gland \\
\hline ADV 4163.03 & $35, \mathrm{M}$ & Cyst \\
\hline ADV 5155.03 & $61, \mathrm{~F}$ & Wound \\
\hline ADV 5347.03 & $39, \mathrm{~F}$ & Amniotic fluid \\
\hline ADV 1417.04 & $29, \mathrm{~F}$ & Phlegmon (groin) \\
\hline NML 96A071 & $20, \mathrm{~F}$ & Blood culture \\
\hline NML 98A053 & $37, \mathrm{~F}$ & Blood culture \\
\hline NML 98A064 & $46, \mathrm{~F}$ & Perinephretic abscess \\
\hline NML 99A033 & $19, \mathrm{~F}$ & Blood culture \\
\hline NML 99A063 & $34, \mathrm{~F}$ & Blood culture \\
\hline NML 99A086 & $39, \mathrm{~F}$ & Breast-abscess pus \\
\hline NML 99A098 & Unknown, F & Blood culture \\
\hline NML 00A086 & $40, \mathrm{~F}$ & Blood culture \\
\hline NML 00A097 & $33, \mathrm{~F}$ & Blood culture \\
\hline NML 01A080 & $79, \mathrm{~F}$ & Blood culture \\
\hline NML 01A081 & $16, \mathrm{~F}$ & Blood culture \\
\hline \multicolumn{3}{|c|}{ D. propionicifaciens sp. nov. } \\
\hline ADV $1053.03^{\mathrm{T}}$ & $89, \mathrm{M}$ & Pressure ulcer (sacrum) \\
\hline ADV 4162.03 & $19, \mathrm{M}$ & Semen \\
\hline ADV 2463.03 & $79, \mathrm{M}$ & Abscess (groin) \\
\hline ADV 3202.03 & $52, \mathrm{M}$ & Wound \\
\hline
\end{tabular}

${ }^{\star} \mathrm{F}$, Female; M, male.

Nearly-complete 16S rRNA gene sequences were matched with the GenBank and EMBL databases by using BLAST program (Altschul et al., 1997): they displayed the highest similarity with sequences of members of the genus Dialister, which is within the family 'Acidaminococcaceae' (Willems \& Collins, 1995; Garrity \& Holt, 2001). Two clusters of nearlyidentical sequences could be differentiated on the basis of $16 \mathrm{~S}$ rRNA gene sequence similarity being below $94 \cdot 3 \%$ according to LALIGN software (http://www.expasy.org). The first cluster represented by the strain Dialister sp. ADV $04.01^{\mathrm{T}}$ (accession no. AF473837) (Marchandin et al., 2003a) contained 13 isolates sharing at least 99.9\% 16S rRNA gene sequence similarity. Maximum similarity $(92 \cdot 7 \%)$ was found with the sequence of oral strain Dialister sp. GBA27 (accession no. AF287788); sequence similarities with known species are given in Table 2. The second group of clinical isolates included the four strains Dialister sp. ADV $1053.03^{\mathrm{T}}$, ADV 2463.03, ADV 3202.03 and ADV 4162.03, which shared 16S rRNA gene sequence similarity of at least $99 \cdot 6 \%$. The representative strain Dialister sp. ADV $1053.03^{\mathrm{T}}$ showed a maximum similarity of $95 \cdot 2 \%$ with $D$. invisus DSM $15470^{\mathrm{T}}$ (Table 2) and with oral clones and isolates. The same distribution of the isolates in two groups was also observed on the basis of $d n a K$ gene sequence similarities being above $97 \cdot 3$ and $97 \cdot 4 \%$, respectively (Table 2 ).

To reconstruct $16 \mathrm{~S}$ rRNA gene- and dnaK-based phylogeny, DNA sequences were aligned using the DIALIGN program (Morgenstern, 2002). Trees were inferred using the PHYLIP suite of programs (Felsenstein, 1993) by maximum 
Table 2. Genetic and genomic characteristics of Dialister species

All strains contain four rrn operons.

\begin{tabular}{|c|c|c|c|c|}
\hline \multirow[t]{2}{*}{ Characteristic } & \multicolumn{4}{|c|}{ Strain } \\
\hline & 1 & 2 & 3 & 4 \\
\hline \multicolumn{5}{|l|}{ 16S rRNA gene sequence similarity } \\
\hline 1. D. micraerophilus ADV $04.01^{\mathrm{T}}\left(\geqslant 99 \cdot 9 \% \%^{\star}\right)$ & $(100)$ & $94 \cdot 3$ & $92 \cdot 3$ & $92 \cdot 5$ \\
\hline 2. D. propionicifaciens ADV $1053.03^{\mathrm{T}}\left(\geqslant 99 \cdot 6 \%^{*}\right)$ & & $(100)$ & $92 \cdot 7$ & $95 \cdot 2$ \\
\hline 3. D. pneumosintes ATCC $33048^{\mathrm{T}}$ & & & $(100)$ & 93 \\
\hline 4. D. invisus DSM $15470^{\mathrm{T}}$ & & & & $(100)$ \\
\hline \multicolumn{5}{|l|}{ dnaK gene sequence similarity } \\
\hline 1. D. micraerophilus ADV $04.01^{\mathrm{T}}\left(\geqslant 97 \cdot 3 \%{ }^{*}\right)$ & $(100)$ & $78 \cdot 2$ & $79 \cdot 7$ & 77 \\
\hline 2. D. propionicifaciens ADV $1053.03^{\mathrm{T}}\left(\geqslant 97 \cdot 4 \%^{\star}\right)$ & & $(100)$ & $73 \cdot 8$ & $76 \cdot 3$ \\
\hline 3. D. pneumosintes ATCC $33048^{\mathrm{T}}$ & & & $(100)$ & $74 \cdot 4$ \\
\hline 4. D. invisus DSM $15470^{\mathrm{T}}$ & & & & $(100)$ \\
\hline DNA G + C content $(\mathrm{mol} \%)$ & $36 \cdot 3$ & ND & 35 & $45-46$ \\
\hline Total genome size $(\mathrm{Mb})$ & $1 \cdot 35 \dagger$ & $1 \cdot 7 \ddagger$ & $1 \cdot 34$ & $1 \cdot 97$ \\
\hline
\end{tabular}

ND, Not determined.

${ }^{\star}$ Intraspecies sequence similarity.

$\dagger$ Mean determined for seven D. micraerophilus strains, including the type strain.

$¥$ Mean determined for four $D$. propionicifaciens strains, including the type strain.

likelihood (Olsen et al., 1994), maximum parsimony (Kluge \& Farris, 1969) and neighbour joining (algorithm F84 for the distance matrix) (Saitou \& Nei, 1987; Kishino \& Hasegawa, 1989). The robustness of the trees was evaluated with 1000 bootstrap replications using the SEQBOOT and CONSENSE programs (Felsenstein, 1993). The evolutionary distance tree based on 16S rRNA gene sequences was obtained for members of the genus Dialister, including known species, the strains in this study, oral isolates of unnamed species and oral clones, and is available as a supplementary figure in IJSEM Online. Phylogenetic analysis confirmed that all isolates belonged to the genus Dialister but that they formed two branches distinct from those of $D$. invisus and $D$. pneumosintes. These two groups corresponded to two distinct and robust phylogenetic clades supported by bootstrap values of $100 \%$. Similar branching of the different species was observed whichever algorithm was used to reconstruct phylogenetic trees. The two groups of related strains will be named Dialister micraerophilus sp. nov. and Dialister propionicifaciens sp. nov. The phylogenetic neighbourhood observed between several Dialister sp. oral clones or oral isolates and D. invisus suggested that at least Dialister sp. oral isolate E2_20 E1 could be considered as D. invisus. This suggestion is also supported by both the high level of $16 \mathrm{~S}$ rRNA gene sequence similarity observed between the corresponding sequences $(99 \cdot 8 \%)$ and the anatomical site reported for this isolate. The dnaK-based phylogeny (Fig. 1) is congruent with that obtained after $16 \mathrm{~S}$ rRNA gene sequence analysis, there being two well-separated lineages, supported by high bootstrap values, corresponding to $D$. micraerophilus and D. propionicifaciens. D. invisus and D. pneumosintes formed two other distinct lineages. The branching of the different clusters was identical in trees reconstructed by the different methods. In both the $D$. micraerophilus cluster and the D. propionicifaciens cluster, subgroups of strains can be distinguished because of the higher variability of the $d n a K$ gene relative to that of the $16 \mathrm{~S}$ rRNA gene.

The DNA G + C content, determined by HPLC at the Identification Service of the Deutsche Sammlung von Mikroorganismen und Zellkulturen (Braunschweig, Germany), for strain D. micraerophilus ADV $04.01^{\mathrm{T}}$ was $36 \cdot 3 \mathrm{~mol} \%$. This value is clearly distinct from that of D. invisus, and is closer to, albeit different from, that of $D$. pneumosintes ATCC $33048^{\mathrm{T}}$ (Downes et al., 2003) (Table 2). The DNA $\mathrm{G}+\mathrm{C}$ content of strain D. propionicifaciens ADV $1053.03^{\mathrm{T}}$ could not be determined, because the very limited growth of the strain in broth media meant that it was not possible to obtain enough biomass for efficient $\mathrm{G}+\mathrm{C}$-content analysis. Therefore, another genomic approach, PFGE, was used to investigate the total DNA content of the strains, since the large-scale chromosome structure was previously described as a sensitive indicator of phylogenetic relationships between bacteria (Liu et al., 1999). The number and sizes of bacterial chromosomes were analysed by PFGE of intact DNAs prepared in agarose plugs as described previously (Marchandin et al., 2001). The PFGE conditions consisted of pulse ramps of 90-300 s for $45 \mathrm{~h}$ at $4 \cdot 5 \mathrm{~V} \mathrm{~cm}^{-1}$. Mapping experiments with the intron-encoded endonuclease I-CeuI (New England Biolabs) were undertaken to determine the rrn skeletons, as described previously (Marchandin et al., 2003a). PFGE experiments were performed in a CHEF-DRII apparatus (Bio-Rad) on $0.8 \%$ agarose gel in $0.5 \times$ TBE. Seven of 


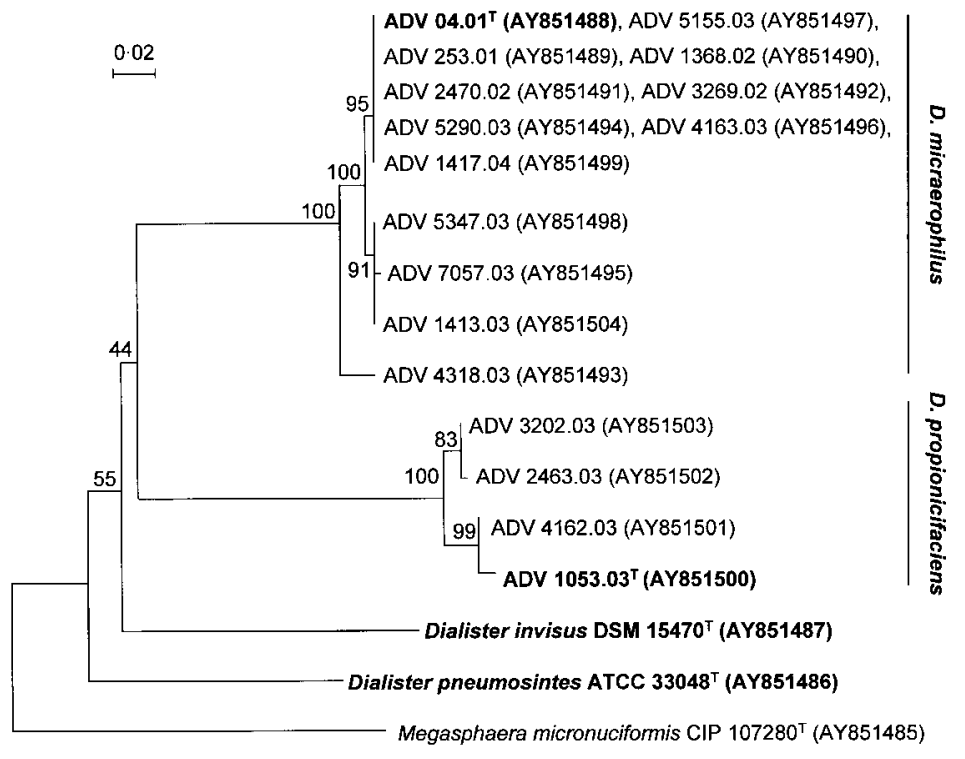
Fig. 1. Neighbour-joining tree based on par- tial dnaK gene sequences (532 nt), showing the relationships between $D$. micraerophilus, $D$. propionicifaciens, D. pneumosintes and D. invisus. Megasphaera micronuciformis was the outgroup organism. Numbers at nodes indicate percentages of bootstrap support, based on analysis of 1000 replicates. Bar, 0.02 substitutions per site.

the 13 French $D$. micraerophilus strains and the four $D$. propionicifaciens isolates were studied in comparison with D. pneumosintes ATCC $33048^{\mathrm{T}}$ and D. invisus DSM $15470^{\mathrm{T}}$. This analysis of genomic organization revealed that all the strains studied possess a unique and circular chromosome (data not shown); chromosome sizes are given in Table 2. Again, two clusters of clinical strains can be distinguished according to chromosomal size. It is interesting to note that the genome size of D. invisus DSM $15470^{\mathrm{T}}$ was about $50 \%$ larger than the genome sizes of $D$. micraerophilus and D. pneumosintes ATCC $33048^{\mathrm{T}}$. The size of the D. invisus genome in the context of its relatively high $\mathrm{G}+\mathrm{C}$ content suggested a recent and massive event of lateral transfer. ICeuI profiles showed that all the strains tested possess four $r r n$ operons (Table 2). However, each species displayed a specific I-CeuI profile. In particular, the I-CeuI fragments clearly differentiated the genomes of the two species showing similar genome sizes (D. pneumosintes and D. micraerophilus) (data not shown).

All of the isolates formed circular, convex, translucent and tiny colonies on Columbia sheep-blood agar plates. Even after prolonged incubation, the colonies were less than $0.5 \mathrm{~mm}$ in diameter, making their recovery in mixed anaerobic cultures relatively difficult. The bacteria stained Gram-negative and were non-sporing, non-motile and coccoid to coccobacillary, occurring as single cells but sometimes in pairs or clumps. They were prepared as described previously for both ultrathin-section observation and negative staining (Marchandin et al., 2003a) with the following modification. Grids were negatively stained with phosphotungstic acid (1\%) for $1 \mathrm{~min}$. Samples were observed under a Hitachi H7100 electron microscope. D. micraerophilus ADV $04.01^{\mathrm{T}}$ and D. propionicifaciens $\mathrm{ADV}$ $1053.03^{\mathrm{T}}$ showed similar morphology, being small coccobacilli about $0 \cdot 2-0 \cdot 4 \times 0 \cdot 3-0 \cdot 6 \mu \mathrm{m}$ in size. Both strains displayed a very convoluted cell surface after negative staining (Fig. 2) and showed the typical Gram-negative surface layers, in ultrathin sections (Fig. 3), previously
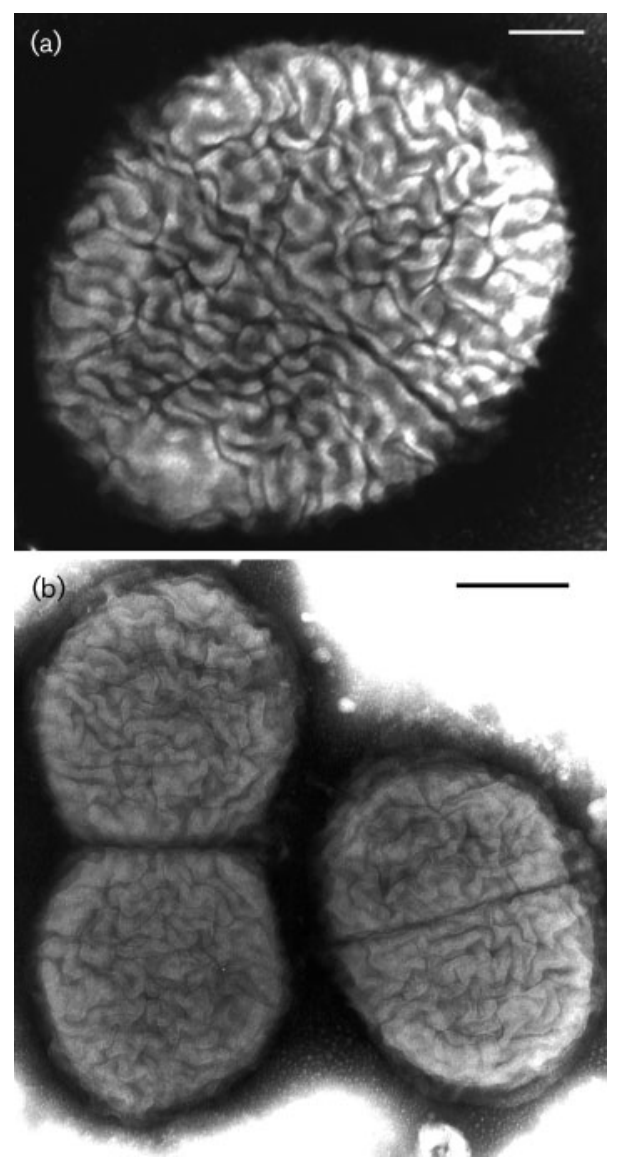

Fig. 2. General morphology after negative staining of $D$. micraerophilus ADV $04.01^{\top}$ (a) and D. propionicifaciens ADV $1053.03^{\top}$ (b). Bars: $100 \mathrm{~nm}$ (a) and $200 \mathrm{~nm}$ (b). 

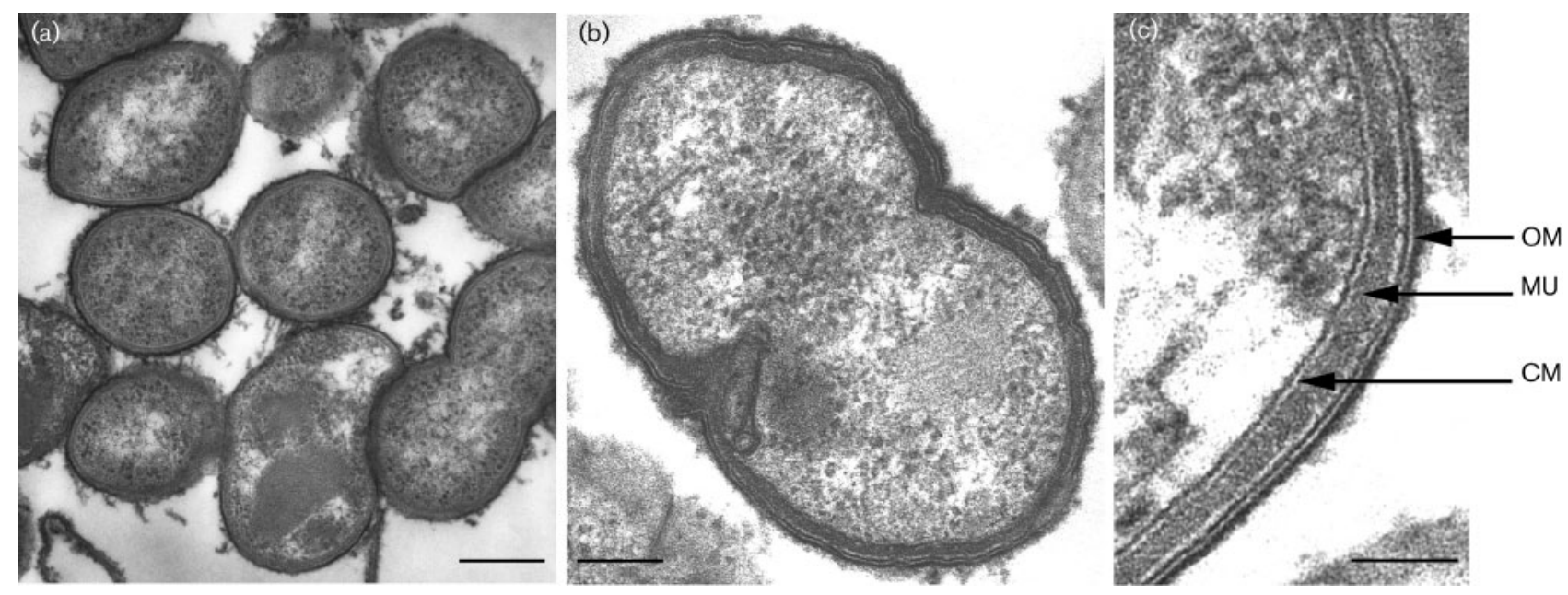

Fig. 3. Ultrastructure of $D$. micraerophilus strain $A D V 04.01^{\top}$, observed using electron microscopic examination of ultrathin sections. ( $a, b)$ General morphology; (c) cell wall and membranes. OM, Outer membrane; MU, peptidoglycan layer; CM, cytoplasmic membrane. Bars: $250 \mathrm{~nm}$ (a) and $100 \mathrm{~nm}$ (b, c).

described for several members of the family 'Acidaminococcaceae' (Jumas-Bilak et al., 2004).

The strains were identified according to the procedures of Holdeman et al. (1977). Since the majority of the French clinical strains were able to grow under microaerophilic conditions (Table 3), the genus Dialister has to be redefined as including microaerophiles, as previously described for Wolinella (Han et al., 1991), and should be considered as anaerobic and microaerophilic rather than simply anaerobic. For further biochemical characterization, the strains were grown anaerobically in trypticase/glucose/yeast extract broth (Carlier, 1985) and incubated at $37^{\circ} \mathrm{C}$ for $72 \mathrm{~h}$ in an anaerobic jar containing $\mathrm{H}_{2} / \mathrm{CO}_{2} / \mathrm{N}_{2}(5: 5: 90$, by vol.). All clinical strains were asaccharolytic and were non-reactive in conventional biochemical tests (nitrate reduction, production of gas, catalase, indole and urease). They also did not modify milk or gelatin. Enzymic profiles obtained with Rapid ID 32A (API bioMérieux) highlighted phenotypic heterogeneity within the genus Dialister (Table 3 ). The results obtained for D. pneumosintes ATCC $33048^{\mathrm{T}}$ differed from those reported previously by Downes et al. (2003), since only arginine arylamidase activity was detected (Downes et al., 2003). Alanine arylamidase and serine arylamidase activities were found in 64 and $71 \%$ of the D. micraerophilus strains, respectively, and phenylalanine arylamidase and tyrosine arylamidase activities appeared to be specific to this species (Table 3 ). D. propionicifaciens possessed some physiological characteristics in common with the members of the genus Veillonella. They shared the same metabolic profile, with the production of acetic, propionic and lactic acids, although $D$. propionicifaciens produced these acids in smaller amounts. Sodium succinate enhanced the growth of $D$. propionicifaciens isolates, whereas lactate and glutamate did not, and subsequent GC analysis revealed that the four strains produced a large amount of propionate from trypticase/glucose/yeast extract supplemented with sodium succinate. D. propionicifaciens was able to decarboxylate succinate to propionate, similarly to the members of the genus Veillonella. The net yield of the propionate decarboxylation was $1 \mathrm{~mol}$ propionate per mol succinate consumed. However, the two types of organism can be easily differentiated. Indeed, Veillonella species ferment lactate to acetate and propionate, produce gas and reduce nitrate (Rogosa, 1984), whereas D. propionicifaciens does not.

DNA from the Canadian isolates was extracted, the $16 \mathrm{~S}$ rRNA gene amplified and sequenced, and BLAST analyses done as described previously (Bernard et al., 2002). Eleven clinical isolates of an unidentified Gram-negative coccobacillus isolated in Canada were affiliated to the species $D$. micraerophilus on the basis of the high levels of $16 \mathrm{~S}$ rRNA gene sequence similarity ( $>99.9 \%$ ) observed between these isolates and D. micraerophilus ADV $04.01^{\mathrm{T}}$. The topology of the 16S rRNA gene-based phylogenetic tree reconstructed in a previous unpublished work (Bernard et al., 2003) showed that all the Canadian isolates grouped together with the type strain of D. micraerophilus, ADV $04.01^{\mathrm{T}}$, without any phylogenetic divergence, as was also observed for the French isolates (data not shown). These isolates were similar to the French D. micraerophilus isolates in terms of all the phenotypic characteristics determined. However, some strains were found to be so fastidious that one or more of the biochemical or chemotaxonomic tests could not be carried out, in spite of repeated attempts. The isolates that yielded sufficient bacterial load after growth in broth were analysed for their cellular fatty acid (CFA) composition as described previously, using the Sherlock system (MIDI) (Bernard et al., 2002); results are available in a supplementary table in 
Table 3. Phenotypic characteristics of $D$. pneumosintes and $D$. invisus type strains and D. micraerophilus and $D$. propionicifaciens clinical isolates from France

\begin{tabular}{|c|c|c|c|c|}
\hline Test & $\begin{array}{l}\text { D. pneumosintes } \\
\text { ATCC } 33048^{\mathrm{T}}\end{array}$ & $\begin{array}{c}\text { D. invisus } \\
\text { DSM } 15470^{\mathrm{T}}\end{array}$ & $\begin{array}{l}\text { D. micraerophilus } \\
(n=13)\end{array}$ & $\begin{array}{l}\text { D. propionicifaciens } \\
(n=4)\end{array}$ \\
\hline Growth under microaerophilic conditions ${ }^{\star}$ & - & - & $+(13 / 13)$ & $+(2 / 4)$ \\
\hline \multicolumn{5}{|l|}{ Susceptibility to special-potency discs $\dagger$} \\
\hline Kanamycin $(500 \mu \mathrm{g})$ & S & S & S & S \\
\hline Bile (1 mg) & S & S & S & S \\
\hline Vancomycin $(5 \mu \mathrm{g})$ & $\mathrm{R}$ & $\mathrm{R}$ & $\mathrm{R}$ & $\mathrm{R}$ \\
\hline Metronidazole $(50 \mu \mathrm{g})$ & S & S & $S(12 / 13)$ & S \\
\hline Colistin $(10 \mu \mathrm{g})$ & $\mathrm{R}$ & S & $\mathrm{R}(11 / 13)$ & $\mathrm{R}(3 / 4)$ \\
\hline \multicolumn{5}{|l|}{ Rapid ID 32A results: $\neq$} \\
\hline Code for type strain & 0000012401 & 0000000000 & 2000013305 & 0000000000 \\
\hline Phenylalanine arylamidase activity & - & - & $+(13 / 13)$ & - \\
\hline Tyrosine arylamidase activity & - & - & $+(13 / 13)$ & - \\
\hline $\begin{array}{l}\text { Enhancement of growth in TGY broth } \\
\text { by sodium succinate\$ }\end{array}$ & - & + & - & + \\
\hline Metabolic end-productsII & $\begin{array}{c}\mathrm{A}, \mathrm{P}, \mathrm{L}, \mathrm{S} \\
\text { (trace amounts) }\end{array}$ & $\begin{array}{l}\text { A, P (trace } \\
\text { amounts) }\end{array}$ & $\begin{array}{c}\text { Not detected } \\
\text { (in significant quantities) }\end{array}$ & $\mathrm{A}, \mathrm{P}, \mathrm{L}$ \\
\hline
\end{tabular}

${ }^{*}$ Tested using Campygen Compact (Oxoid Unipath); D. propionicifaciens strains ADV $1053.03^{\mathrm{T}}$ and ADV 4162.03 were able to grow under microaerophilic conditions.

†Used as described by Jousimies-Somer et al. (2002). R, Resistant; s, susceptible.

$\ddagger$ Used as recommended by the manufacturer; in particular, a bacterial inoculum of 4 McFarland standard was strictly adhered to. D. pneumosintes ATCC $33048^{\mathrm{T}}$ showed the following activities: arginine arylamidase, leucine arylamidase, glycine arylamidase and histidine arylamidase. $D$. micraerophilus ADV $04.01^{\mathrm{T}}$ showed, in addition, arginine dihydrolase and phenylalanine, tyrosine, alanine and serine arylamidase activities and lacked glycine and histidine arylamidase activities.

\$TGY, Trypticase/glucose/yeast extract. Succinate was completely decarboxylated into propionate after 9 days growth for D. invisus DSM $15470^{\mathrm{T}}$ and after 4 days for D. propionicifaciens strains.

IIAssayed by quantitative GC as described previously (Carlier, 1985). A, Acetic acid; P, propionic acid; L, lactic acid; S, succinic acid. Data for D. pneumosintes ATCC $33048^{\mathrm{T}}$ were from Moore \& Moore (1994) and data for D. invisus were from Downes et al. (2003).

IJSEM Online. In some instances, the analysis could only be interpreted after the use of specific techniques to concentrate and maximize the bacterial loads, as found previously for D. pneumosintes (Moore et al., 1994). Anaer1 was used as the Sherlock method, and the profiles generated were compared with the commercial library MOORE, version 3.8. CFA data for D. micraerophilus strains were analysed and stored in a library entry created using LIBRARY GENERATION system software (MIDI) within an in-house library, LCDC2. The D. micraerophilus in-house-entry data were found to be qualitatively consistent with the genus Dialister (Moore et al., 1994; Downes et al., 2003). The Canadian D. pneumosintes isolates were found to have a CFA profile essentially identical to that found previously for D. pneumosintes (Moore et al., 1994). The D. pneumosintes entry demonstrated a reproducible, quantitative difference for the volume of CFAs 3-OH $14: 0$ and 15:0 dimethyl acetal (MIDI summed feature 5), which averaged $9 \%$ of total CFAs, whereas this CFA was not detected for D. micraerophilus isolates.

Finally, the D. micraerophilus clinical isolates described in this study, whether derived from patients in France or Canada, were essentially identical with respect to the species description.

\section{Emended description of Dialister (ex Bergey et al. 1923) Moore and Moore 1994}

The description is as emended by Downes et al. (2003), with the following modifications: species are anaerobic or microaerophilic.

\section{Description of Dialister micraerophilus sp. nov.}

Dialister micraerophilus (mic.rae' ro.phi.lus. Gr. adj. mikros small; Gr. n. aer air; N.L. adj. philus from Gr. adj. philos loving; N.L. masc. adj. micraerophilus slightly air-loving, referring to the ability of the species to grow under microaerophilic conditions).

Cells are coccoid to coccobacillary $(0 \cdot 2-0 \cdot 4 \times 0 \cdot 3-0 \cdot 6 \mu \mathrm{m})$, occurring singly, in pairs or in clumps. Gram-negative, nonmotile, non-sporulating and with a convoluted cell surface. Colonies on Columbia sheep-blood agar are $0.5 \mathrm{~mm}$ in diameter, circular, convex and translucent. Anaerobic and microaerophilic. Unreactive in most conventional tests. Among the positive reactions in the Rapid ID 32A profile, phenylalanine arylamidase and tyrosine arylamidase activities are specific for D. micraerophilus. Metabolic endproducts are not detected in any significant quantities. Can 
be differentiated from other species of the genus Dialister by phenylalanine arylamidase and tyrosine arylamidase activity detection and by $16 \mathrm{~S}$ rRNA gene and dnaK sequencing, and from $D$. pneumosintes by CFA-composition analysis. The DNA G + C content of the type strain is $36 \cdot 3 \mathrm{~mol} \%$.

The type strain is strain ADV $04.01^{\mathrm{T}}\left(=\mathrm{AIP} 25.04^{\mathrm{T}}=\mathrm{CIP}\right.$ $108278^{\mathrm{T}}=$ CCUG $48837^{\mathrm{T}}$ ), isolated from human clinical samples.

\section{Description of Dialister propionicifaciens sp. nov.}

Dialister propionicifaciens (pro.pi.o.ni'ci.fa'ci.ens. N.L. n. acidum propionicum propionic acid; L. v. facio -ere to produce; N.L. part. adj. propionicifaciens propionic acidproducing).

Cells are coccoid to coccobacillary $(0 \cdot 2-0 \cdot 4 \times 0 \cdot 3-0 \cdot 6 \mu \mathrm{m})$, occurring singly, in pairs or in clumps. Gram-negative, nonmotile, non-sporulating and with a convoluted cell surface. Colonies on Columbia sheep-blood agar are $0.5 \mathrm{~mm}$ in diameter, circular, convex and translucent. Anaerobic and microaerophilic. Unreactive in most conventional tests. Metabolic end-products consist of small amounts of acetic acid, propionic acid and lactic acid. Propionate is produced when the growth medium is supplemented with sodium succinate. The net yield of the propionate decarboxylation is 1 mol propionate per mol succinate consumed. Can be differentiated from other species of the genus Dialister by propionic acid production, by $16 \mathrm{~S}$ rRNA gene and dnaK sequencing and by genome sizing.

The type strain is ADV $1053.03^{\mathrm{T}}$ (=AIP $26.04^{\mathrm{T}}=\mathrm{CIP}$ $108336^{\mathrm{T}}=$ CCUG $\left.49291^{\mathrm{T}}\right)$ and a reference strain is ADV 3202.03 ( = AIP 126.04=CIP 108582). Isolated from human clinical samples.

\section{Emended description of Dialister pneumosintes (Olitsky and Gates 1921) Moore and Moore 1994}

The description is as emended by Downes et al. (2003), with the following modifications: the type strain shows arginine arylamidase, leucine arylamidase, glycine arylamidase and histidine arylamidase activities in Rapid ID 32A (profile 0000012401). Can be differentiated from other species of the genus Dialister by $16 \mathrm{~S}$ rRNA gene and $d n a K$ sequencing and from $D$. micraerophilus by CFA-composition analysis.

\section{Acknowledgements}

We are indebted to J. P. Euzéby for helpful comments on nomenclatural issues. We thank I. Diego, R. Devine, M. BedoraFaure, G. K'ouas and M. Manich for excellent technical assistance with characterization of the French isolates and C. Munro, L. Shuttleworth and E. Ongsansoy for their technical assistance with characterization of the Canadian isolates. This work is partly supported by the association ADEREMPHA (Montpellier, France). This work was presented, in part, at the 103rd General Meeting of American Society for Microbiology, Washington, DC, 18-22 May 2003, as poster no. R-030-103.

\section{References}

Altschul, S. F., Madden, T. L., Schäffer, A. A., Zhang, J., Zhang, Z., Miller, W. \& Lipman, D. J. (1997). Gapped BLAST and PSI-BLAST: a new generation of protein database search programs. Nucleic Acids Res 25, 3389-3402.

Bergey, D. H., Harrison, F. C., Breed, R. S., Hammer, B. W. \& Huntoon, F. M. (1923). In Bergey's Manual of Determinative Bacteriology, pp. 271-272. Baltimore: Williams \& Wilkins.

Bernard, K., Shuttleworth, L., Munro, C., Forbes-Faulkner, J. C., Pitt, D., Norton, J. H. \& Thomas, A. D. (2002). Propionibacterium australiense sp. nov. derived from granulomatous bovine lesions. Anaerobe 8, 41-47.

Bernard, K. A., Shuttleworth, L., Munro, C., Marchandin, H., JeanPierre, H., Carlier, J. \& Jumas-Bilak, E. (2003). Proposal of Dialister microaerophilus sp. nov., a microaerophilic, gram-negative coccobacillus recovered from human clinical materials in France and Canada. In Abstracts of the 103rd General Meeting of the American Society for Microbiology, 18-22 May 2003, Washington, DC. Poster R-030-103.

Carlier, J.-P. (1985). Gas chromatography of fermentation products: its application in diagnosis of anaerobic bacteria. Bull Inst Pasteur 83, 57-69.

Carlier, J.-P., Marchandin, H., Jumas-Bilak, E., Lorin, V., Henry, C., Carrière, C. \& Jean-Pierre, H. (2002). Anaeroglobus geminatus gen. nov., sp. nov., a novel member of the family Veillonellaceae. Int J Syst Evol Microbiol 52, 983-986.

Doan, N., Contreras, A., Flynn, J., Slots, J. \& Chen, C. (2000). Molecular identification of Dialister pneumosintes in subgingival plaque of humans. J Clin Microbiol 38, 3043-3047.

Domann, E., Hong, G., Imirzalioglu, C., Turschner, S., Kuhle, J., Watzel, C., Hain, T., Hossain, H. \& Chakraborty, T. (2003). Cultureindependent identification of pathogenic bacteria and polymicrobial infections in the genitourinary tract of renal transplant recipients. $J$ Clin Microbiol 41, 5500-5510.

Downes, J., Munson, M. \& Wade, W. G. (2003). Dialister invisus sp. nov., isolated from the human oral cavity. Int J Syst Evol Microbiol 53, 1937-1940.

Felsenstein, J. (1993). PHYLIP (phylogeny inference package), version 3.5c. Distributed by the author. Department of Genome Sciences, University of Washington, Seattle, USA.

Garrity, G. M. \& Holt, J. G. (2001). Taxonomic outline of the Archaea and Bacteria. In Bergey's Manual of Systematic Bacteriology, 2nd edn, vol. 1, pp. 155-166. Edited by D. R. Boone, R. W. Castenholz \& G. M. Garrity. New York: Springer.

Goldstein, E. J., Citron, D. M. \& Finegold, S. M. (1984). Role of anaerobic bacteria in bite-wound infections. Rev Infect Dis 6, S177-S183.

Han, Y.-H., Smibert, R. M. \& Krieg, N. R. (1991). Wolinella recta, Wolinella curva, Bacteroides ureolyticus, and Bacteroides gracilis are microaerophiles, not anaerobes. Int J Syst Bacteriol 41, 218-222.

Holdeman, L. V. \& Moore, W. E. C. (1970). Bacteroides. In Outline of Clinical Methods in Anaerobic Bacteriology, 2nd revision. Edited by E. P. Cato, C. S. Cummins, L. V. Holdeman, J. L. Johnson, W. E. C. Moore, R. M. Smibert \& L. D. S. Smith. Blacksburg, VA: Virginia Polytechnic Institute. 
Holdeman, L. V., Cato, E. P. \& Moore, W. E. C. (1977). Anaerobe Laboratory Manual, 4th edn. Blacksburg, VA: Virginia Polytechnic Institute and State University.

Jousimies-Somer, H. R., Summanen, P., Citron, D. M., Baron, E. J., Wexler, H. M. \& Finegold, S. M. (2002). Wadworth - KTL Anaerobic Bacteriology Manual, 6th edn. Belmont, CA: Star Publishing Company. Jumas-Bilak, E., Carlier, J.-P., Jean-Pierre, H., Teyssier, C., Gay, B., Campos, J. \& Marchandin, H. (2004). Veillonella montpellierensis sp. nov., a novel, anaerobic, Gram-negative coccus isolated from human clinical samples. Int J Syst Evol Microbiol 54, 1311-1316.

Kishino, H. \& Hasegawa, M. (1989). Evaluation of the maximum likelihood estimate of the evolutionary tree topologies from DNA sequence data, and the branching order in Hominoidea. J Mol Evol 29, 170-179.

Kluge, A. \& Farris, J. (1969). Quantitative phyletics and the evolution of anurans. Syst Zool 18, 1-32.

Liu, S.-L., Schryvers, A. B., Sanderson, K. E. \& Johnston, R. N. (1999). Bacterial phylogenetic clusters revealed by genome structure. J Bacteriol 181, 6747-6755.

Marchandin, H., Jean-Pierre, H., Carrière, C., Canovas, F., Darbas, H. \& Jumas-Bilak, E. (2001). Prosthetic joint infection due to Veillonella dispar. Eur J Clin Microbiol Infect Dis 20, 340-342.

Marchandin, H., Jumas-Bilak, E., Gay, B., Teyssier, C., Jean-Pierre, H., Siméon de Buochberg, M., Carrière, C. \& Carlier, J.-P. (2003a). Phylogenetic analysis of some Sporomusa sub-branch members isolated from human clinical specimens: description of Megasphaera micronuciformis sp. nov. Int J Syst Evol Microbiol 53, 547-553.

Marchandin, H., Teyssier, C., Siméon de Buochberg, M., JeanPierre, H., Carrière, C. \& Jumas-Bilak, E. (2003b). Intra-chromosomal heterogeneity between the four 16S rRNA gene copies in the genus Veillonella: implications for phylogeny and taxonomy. Microbiology 149, 1493-1501.

Moore, L. V. H. \& Moore, W. E. C. (1994). Oribaculum catoniae gen. nov., sp. nov.; Catonella morbi gen. nov., sp. nov.; and Dialister pneumosintes gen. nov., comb. nov., nom. rev., anaerobic gramnegative bacilli from the human gingival crevice. Int J Syst Bacteriol 44, 187-192.

Moore, L. V. H., Bourne, D. M. \& Moore, W. E. C. (1994). Comparative distribution and taxonomic value of cellular fatty acids in thirty-three genera of anaerobic Gram-negative bacilli. Int J Syst Bacteriol 44, 338-347.

Morgenstern, B. (2002). A simple and space-efficient fragmentchaining algorithm for alignment of DNA and protein sequences. Appl Math Lett 15, 11-16.

Olsen, G. J., Matsuda, H., Hagstrom, R. \& Overbeek, R. (1994). fastDNAml: a tool for construction of phylogenetic trees of DNA sequences using maximum likelihood. Comput Appl Biosci 10, 41-48. Paster, B. J., Boches, S. K., Galvin, J. L., Ericson, R. E., Lau, C. N., Levanos, V. A., Sahasrabudhe, A. \& Dewhirst, F. E. (2001). Bacterial diversity in human subgingival plaque. J Bacteriol 183, 3770-3783.

Rogosa, M. (1984). Anaerobic Gram-negative cocci. In Bergey's Manual of Systematic Bacteriology, vol. 1, pp. 680-685. Edited by N. R. Krieg \& J. G. Holt. Baltimore: Williams \& Wilkins.

Rolph, H. J., Lennon, A., Riggio, M. P., Saunders, W. P., MacKenzie, D., Coldero, L. \& Bagg, J. (2001). Molecular identification of microorganisms from endodontic infections. J Clin Microbiol 39, 3282-3289.

Rousée, J. M., Bermond, D., Piémont, Y., Tournoud, C., Heller, R., Kehrli, P., Harlay, M. L., Monteil, H. \& Jaulhac, B. (2002). Dialister pneumosintes associated with human brain abscesses. J Clin Microbiol 40, 3871-3873.

Saitou, N. \& Nei, M. (1987). The neighbor-joining method: a new method for reconstructing phylogenetic trees. Mol Biol Evol 4, 406-425.

Willems, A. \& Collins, M. D. (1995). Phylogenetic placement of Dialister pneumosintes (formerly Bacteroides pneumosintes) within the Sporomusa subbranch of the Clostridium subphylum of the grampositive bacteria. Int J Syst Bacteriol 45, 403-405. 